\title{
Biological drugs in the treatment of atopic dermatitis - recommendations of the Polish Dermatological Society, the Polish Society of Allergology, the Polish Pediatric Society and the Polish Society of Family Medicine
}

\author{
Leki biologiczne w terapii atopowego zapalenia skóry - rekomendacje Polskiego \\ Towarzystwa Dermatologicznego, Polskiego Towarzystwa Alergologicznego, \\ Polskiego Towarzystwa Pediatrycznego oraz Polskiego Towarzystwa Medycyny \\ Rodzinnej
}

Roman J. Nowicki', Magdalena Trzeciak', Lidia Rudnicka², Jacek Szepietowski³, Marek Kulus', Maciej Kupczyk', Agnieszka Mastalerz-Migas ${ }^{6}$, Jaroslaw Peregud-Pogorzelski', Karina Jahnz-Różyk', Joanna Narbuttt', Magdalena Czarnecka-

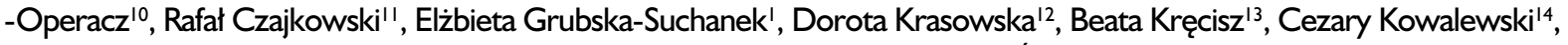
Aleksandra Lesiak ${ }^{8}$, Małgorzata Olszewska², Zbigniew Samochocki², Radosław Śpiewak ${ }^{15}$, Aleksandra Wilkowska'

\footnotetext{
'Department of Dermatology, Venereology and Allergology, Medical University of Gdansk, Gdansk, Poland 2Department of Dermatology, Medical University of Warsaw, Warsaw, Poland

${ }^{3}$ Department of Dermatology, Venereology and Allergology, Medical University of Wroclaw, Wroclaw, Poland ${ }^{4}$ Department of Pediatric Pneumonology and Allergology, Medical University of Warsaw, Warsaw, Poland ${ }^{5}$ Department of Internal Medicine, Asthma and Allergy, Medical University of Lodz, Lodz, Poland ${ }^{6}$ Department of Family Medicine, Medical University of Wroclaw, Wroclaw, Poland

${ }^{7}$ Department of Pediatrics and Pediatric Oncology, Pomeranian Medical University, Szczecin, Poland

${ }^{8}$ Department of Internal Medicine, Pneumonology, Allergology and Clinical Immunology, Military Medical Institute, Warsaw, Poland

'Department of Dermatology, Pediatric and Oncological Dermatology, Medical University of Lodz, Poland

${ }^{10}$ Department of Dermatology, Poznan University of Medical Sciences, Poznan, Poland

" Department of Dermatology and Venereology, "Ludwik Rydygier" Collegium Medicum in Bydgoszcz, Nicolaus Copernicus University in Torun, Poland

'2Department of Dermatology, Venereology and Pediatric Dermatology, Medical University of Lublin, Lublin, Poland

${ }^{13}$ Department of Dermatology, The Faculty of Medicine and Health Sciences, Jan Kochanowski University, Kielce, Poland

${ }^{14}$ Department of Dermatology and Immunodermatology, Medical University of Warsaw, Warsaw, Poland

${ }^{15}$ Department of Experimental Dermatology and Cosmetology, Jagiellonian University Medical College, Krakow, Poland
}

'Katedra i Klinika Dermatologii, Wenerologii i Alergologii, Gdański Uniwersytet Medyczny, Gdańsk, Polska
2Katedra i Klinika Dermatologiczna, Warszawski Uniwersytet Medyczny, Warszawa, Polska
${ }^{3}$ Katedra i Klinika Dermatologii, Wenerologii i Alergologii, Uniwersytet Medyczny we Wrocławiu, Polska
${ }^{4}$ Klinika Pneumonologii i Alergologii Wieku Dziecięcego, Warszawski Uniwersytet Medyczny, Warszawa, Polska
${ }^{5}$ Klinika Chorób Wewnętrznych, Astmy i Alergii, Uniwersytet Medyczny w Łodzi, Polska
${ }^{6}$ Katedra i Zakład Medycyny Rodzinnej, Uniwersytet Medyczny we Wroctawiu, Polska
${ }^{7}$ Klinika Pediatrii i Onkologii Dziecięcej, Pomorski Uniwersytet Medyczny w Szczecinie, Polska
${ }^{8}$ Klinika Chorób Wewnętrznych, Pneumonologii, Alergologii i Immunologii Klinicznej, Wojskowy Instytut Medyczny, Warszawa, Polska
${ }^{9}$ Klinika Dermatologii, Dermatologii Dziecięcej i Onkologicznej, Uniwersytet Medyczny w Łodzi, Polska
IOKatedra i Klinika Dermatologii, Uniwersytet Medyczny w Poznaniu, Polska
${ }^{11 K a t e d r a ~ D e r m a t o l o g i i ~ i ~ W e n e r o l o g i i, ~ C o l l e g i u m ~ M e d i c u m ~ i m . ~ L u d w i k a ~ R y d y g i e r a ~ w ~ B y d g o s z c z y, ~ U n i w e r s y t e t ~ M i k o ł a j a ~ K o p e r n i k a ~}$
W Toruniu, Polska
${ }^{12 K a t e d r a ~ i ~ K l i n i k a ~ D e r m a t o l o g i i, ~ W e n e r o l o g i i ~ i ~ D e r m a t o l o g i i ~ D z i e c i e ̨ c e j, ~ U n i w e r s y t e t ~ M e d y c z n y ~ w ~ L u b l i n i e, ~ P o l s k a ~}$
${ }^{13 K l i n i k a ~ D e r m a t o l o g i i, ~ W y d z i a ł ~ L e k a r s k i ~ i ~ N a u k ~ o ~ Z d r o w i u, ~ U n i w e r s y t e t ~ J a n a ~ K o c h a n o w s k i e g o ~ w ~ K i e l c a c h, ~ P o l s k a ~}$
${ }^{14 K l i n i k a ~ D e r m a t o l o g i i ~ i ~ I m m u n o d e r m a t o l o g i i, ~ W a r s z a w s k i ~ U n i w e r s y t e t ~ M e d y c z n y, ~ W a r s z a w a, ~ P o l s k a ~}$
${ }^{15}$ Zakład Dermatologii Doświadczalnej i Kosmetologii, Uniwersytet Jagielloński Collegium Medicum, Kraków, Polska

Dermatol Rev/Przegl Dermatol 2020, 107, 409-423

DOl: https://doi.org/10.51/4/dr.2020.10166

This article was originally published as:

Nowicki R.J., Trzeciak M., Rudnicka L., Szepietowski J., Kulus M., Kupczyk M., Mastalerz-Migas A., Peregud-Pogorzelski J., Jahnz-Różyk K., Narbutt J., Czarnecka-Operacz M., Czajkowski R., Grubska-Suchanek E., Krasowska D., Kręcisz B., Kowalewski C., Lesiak A., Olszewska M., Samochocki Z., Śpiewak R., Wilkowska A.: Biological drugs in the treatment of atopic dermatitis current recommendations of the Polish Dermatological Society, the Polish Society of Allergology, the Polish Pediatric Society and the Polish Society of Family Medicine. Adv Dermatol Allergol 2020; XXXVII (5): 617-624. DOI: https://doi.org/I0.5 I I 4/ada.2020. 100496. 


\section{CORRESPONDING AUTHOR/} ADRES DO KORESPONDENCJI: prof. dr hab. n. med.

Roman J. Nowicki

Katedra i Klinika Dermatologii,

Wenerologii i Alergologii

Gdański Uniwersytet Medyczny

ul. Smoluchowskiego 17

80-214 Gdańsk

tel. +48585844010

e-mail: rnowicki@gumed.edu.pl

\begin{abstract}
The basis for development of atopic dermatitis are genetic, immunological and microbiological abnormalities as well as epidermal barrier defects. The course of the disease includes periodic exacerbations and remissions. Its development and course are influenced by numerous environmental and individual factors. In recent decades, in industrialized countries, a threefold increase in the incidence of atopic dermatitis was observed. There also is an increasing number of cases resistant to topical treatment. Effective treatment of atopic dermatitis should provide control of clinical symptoms, prevent exacerbations and improve the quality of life of patients. The multifactorial etiopathogenesis and various endotypes and phenotypes of the disease justify the tendency to optimize and personalize the therapy. Currently, we recommend the use of dupilumab for the treatment of patients from 12 years of age with moderate and severe atopic dermatitis, who do not respond to topical treatment.
\end{abstract}

\section{STRESZCZENIE}

U podłoża rozwoju atopowego zapalenia skóry leżą zaburzenia genetyczne, immunologiczne, mikrobiologiczne oraz defekt bariery naskórkowej, które stanowią główne cele terapeutyczne. Choroba przebiega z okresowymi zaostrzeniami. Na jej rozwój i przebieg wpływają liczne czynniki środowiskowe i osobnicze. W ostatnich dekadach w krajach uprzemysłowionych obserwuje się trzykrotny wzrost zachorowań na atopowe zapalenie skóry oraz coraz więcej przypadków opornych na leczenie miejscowe. Skuteczna terapia atopowego zapalenia skóry powinna kontrolować kliniczne objawy choroby, zapobiegać zaostrzeniom oraz poprawiać jakość życia pacjentów. Wieloczynnikowa etiopatogeneza oraz różnorodne endotypy i fenotypy atopowego zapalenia skóry uzasadniają dążenie do optymalizacji i personalizacji terapii. Aktualnie $\mathrm{u}$ pacjentów od 12. roku życia $\mathrm{z}$ umiarkowanym i ciężkim atopowym zapaleniem skóry, którzy nie reagują na leczenie miejscowe, zaleca się stosowanie dupilumabu.

Key words: biological drugs, dupilumab, atopic dermatitis, therapeutic recommendations.

Słowa kluczowe: leki biologiczne, dupilumab, atopowe zapalenie skóry, rekomendacje terapeutyczne.

\section{INTRODUCTION}

Atopic dermatitis (AD) (ICD-10 L20) is a chronic disease that affects mainly children (10-20\%) and lasts until adulthood in about $1 / 5$ of this group [1]. The prevalence of AD in adults has been estimated at $2.1-4.9 \%$ [2]. In adulthood, the disease appears for the first time in $1 / 4$ adult patients suffering from $\mathrm{AD}$ [3].

In over $60 \%$ of cases, there is an increased risk of developing atopic symptoms from other organs. Atopic dermatitis is the first step in the atopic march, in the course of which the following may develop: food allergy (15\%), allergic rhinitis (34\%) and bronchial asthma (20-35\%). Very severe and persistent

\section{WPROWADZENIE}

Atopowe zapalenie skóry (AZS) (ICD-10 L20) to choroba przewlekła, która występuje głównie u dzieci (10-20\%) i utrzymuje się do wieku dorosłego u ok. 1/5 tej grupy [1]. Częstość występowania AZS u dorosłych oszacowano na 2,1-4,9\% [2]. W wieku dorosłym choroba pojawia się po raz pierwszy u 1/4 dorosłych pacjentów chorujących na AZS [3].

W ponad $60 \%$ przypadków występuje podwyższone ryzyko rozwoju objawów atopowych ze strony innych narządów. Atopowe zapalenie skóry to pierwszy krok w marszu atopowym, w którego przebiegu mogą się rozwinąć: alergia pokarmowa (15\%), alergiczny nieżyt 
itching, hypersensitivity and visible skin inflammation and stigmatization significantly reduce the quality of life and are often the cause of anxiety, sleep disorders, absenteeism at school and work, social isolation and, consequently, depression, mental illness and even suicidal thoughts. Children with AD are more likely to develop abdominal obesity and arterial hypertension $[4,5]$.

Skin diseases associated with atopic dermatitis include ichthyosis (ichthyosis vulgaris), infectious diseases such as impetigo and herpetic eczema (eczema herpeticum), and immune diseases: alopecia areata and vitiligo (vitiligo). White dandruff (pityriasis alba) and keratosis pilaris are common in patients with $\mathrm{AD}[6,7]$.

Cutaneous lymphoma may develop in adults with severe AD. Moreover, the relationship between AD and obesity, metabolic syndrome, cardiovascular diseases and osteoporosis has been described $[8,9]$.

\section{BIOLOGICAL DRUGS IN ATOPIC DERMATITIS}

Modern treatment of AD involves two groups of medicinal products: monoclonal bodies that act precisely to inhibit specific cytokines or their receptors, and agonists or antagonists of small molecules. Action of those latter is even broader. It is now known that, in addition to the defect in the epidermal barrier and disorders of the skin microbiota homeostasis, AD is immunologically characterized by abnormal activity of the Th2 cellular system expressed by excessive activity of cytokines such as IL-4, IL-13, cytokines secreted by Th17, Th22, Th1 lymphocytes and cytokines derived directly from the damaged epidermis (IL-33, TSLP, IL-25) [10-12]. Involvement of the Th2 cellular system seems to be the leading and ethnically or pheno-/endotypically independent factor. Which means it affects every patient with AD [13-15]. Hence, targeting the treatment to suppress the Th2 cellular system seems perfectly justified. In 2017, the Food and Drug Administration (FDA) and European Medicines Agency (EMA) approved the drug dupilumab, the first biological drug in AD for the treatment of its moderate and severe form.

\section{Dupilumab}

Dupilumab is a human IgG4 monoclonal antibody directed against the a subunit of the IL-4 receptor (IL-4Ra), thanks to which it blocks both IL-4 and IL-13. The current approval of the drug covers the treatment of moderate to severe $\mathrm{AD}$ in patients aged 12 years and over.

Efficacy of dupilumab therapy in children from 6 years of age, adolescents and adults

The efficacy and safety of dupilumab as a monotherapy or administered concomitantly with topi- nosa (34\%) i astma oskrzelowa (20-35\%). Bardzo silny i uporczywy świąd, nadwrażliwosć oraz widoczne zmiany zapalne na skórze i stygmatyzacja znacznie obniżają jakość życia i są często przyczyną niepokoju, zaburzeń snu, absencji w szkole i w pracy, izolacji społecznej, a także stanów depresyjnych, chorób psychicznych i myśli samobójczych. Dzieci z AZS są bardziej narażone na otyłość brzuszną i nadciśnienie tętnicze [4, 5].

Do chorób skóry związanych z AZS należą: rybia łuska (ichthyosis vulgaris), choroby infekcyjne, takie jak liszajec (impetigo) i wyprysk opryszczkowaty (eczema herpeticum), oraz immunologiczne, takie jak łysienie plackowate (alopecia areata) i bielactwo (vitiligo). U pacjentów z AZS często występuje łupież biały (pityriasis alba) i rogowacenie mieszkowe (keratosis pilaris) [6, 7].

U osób z AZS o ciężkim przebiegu w wieku dorosłym może się rozwinąć chłoniak skóry. Ponadto opisano związek AZS z otyłością, zespołem metabolicznym, chorobami sercowo-naczyniowymi i osteoporozą [8, 9].

\section{LEKI BIOLOGICZNE W ATOPOWYM ZAPALENIU SKÓRY}

Nowoczesne leczenie AZS obejmuje dwie grupy produktów leczniczych: przeciwciała monoklonalne działające precyzyjnie, hamujące konkretne cytokiny lub ich receptory, oraz agonistów lub antagonistów małych cząsteczek, których działanie jest szersze. Obecnie wiadomo, że równolegle do defektu w barierze naskórkowej oraz zaburzeń homeostazy mikrobioty skóry w AZS występuje immunologicznie nieprawidłowa aktywność układu Th2-komórkowego wyrażająca się nadmierną aktywnością takich cytokin, jak IL-4, IL-13, cytokin wydzielanych przez limfocyty Th17, Th22, Th1 oraz cytokin pochodzących bezpośrednio z uszkodzonego naskórka (IL-33, TSLP, IL-25) [10-12]. Zaangażowanie układu Th2-komórkowego wydaje się głównym czynnikiem, niezależnym etnicznie oraz fenotypowo i endotypowo, czyli dotyczącym każdego pacjenta z AZS [13-15]. Dlatego też kierowanie leczenia na zahamowanie układu Th2-komórkowego jest jak najbardziej uzasadnione. W $2017 \mathrm{r}$. Agencja Żywności i Leków (Food and Drug Administration - FDA) i Europejska Agencja Leków (European Medicines Agency - EMA) wydały zgodę na zarejestrowanie dupilumabu - pierwszego leku biologicznego w AZS do leczenia jego postaci umiarkowanej i ciężkiej.

\section{Dupilumab}

Dupilumab to ludzkie przeciwciało monoklonalne IgG4 skierowane przeciwko podjednostce a receptora dla IL-4 (IL-4Ra), dzięki czemu blokuje zarówno IL-4, jak i IL-13. Aktualna rejestracja leku obejmuje leczenie umiarkowanej do ciężkiej postaci AZS u pacjentów w wieku od 12 lat. 
cal glucocorticoids (GCS) in adults were assessed in randomized, double-blind, placebo-controlled phase IIb trials in 452 patients, trials LIBERTY AD SOLO 1 and LIBERTY AD SOLO 2 in 1379 adult AD patients, and 740 patients in the LIBERTY AD CHRONOS trial lasting up to 52 weeks [16-19]. The trials enrolled patients with a prior inadequate response to topical medications with severe to moderate AD as assessed by investigator's global assessment (IGA) score $\geq 3$, eczema area and severity index (EASI) $\geq 16$, and body surface area (BSA) $\geq 10 \%$. Dupilumab significantly improved the objective and subjective symptoms of $\mathrm{AD}$ and quality of life in patients with moderate to severe AD. A reduction in the SCORAD and EASI-75 scores, as well as a reduction in the severity of pruritus, anxiety/depression and sleep disorders have been observed in adults [16-21]. The drug is administered subcutaneously (s.c.). at the first dose of $600 \mathrm{mg}$, followed by the dose of $300 \mathrm{mg}$ s.c. every 2 weeks.

In the group of young people over 12 years of age, 251 patients with a mean age of $14.5 \pm 1.7$ years were randomized. Majority of these patients had other allergic diseases such as asthma, food allergy, and allergic rhinitis. Dupilumab significantly improved signs, symptoms and quality of life in adolescents with moderate to severe AD, with an acceptable safety profile. Effectiveness of the drug administered every 2 weeks was definitely higher than every 4 weeks [22]. Results were obtained and evaluated after 16 weeks of treatment. The drug is administered subcutaneously at the dose of $200 \mathrm{mg}$ in children weighing $<60 \mathrm{~kg}$ or $300 \mathrm{mg}$ for body weight $\geq 60 \mathrm{~kg}$, every 2 weeks or $300 \mathrm{mg}$ every 4 weeks.

Data are available from the phase III clinical trial of dupilumab treatment with concomitant topical GCSs treatment in children aged 6-11 years with severe AD, with inadequately controlled topical treatment [23]. Three hundred sixty seven children were enrolled in the 16-week study. Dupilumab was effective and improved the quality of life of patients in this age group. Taking into account the effectiveness and side effects, the optimal dose was $300 \mathrm{mg}$ every 4 weeks for children weighing $<30 \mathrm{~kg}$ and $200 \mathrm{mg} \mathrm{ev}-$ ery 2 weeks for children weighing $\geq 30 \mathrm{~kg}$ [23]. Data from registries and descriptions of patients treated with dupilumab, in real life, apart from clinical trials, indicate comparable results to those obtained during clinical trials [24-29].

Adverse reactions during dupilumab therapy in children from 6 years of age, adolescents and adults

The most common adverse reaction observed in $22.1 \%$ of dupilumab users in adult clinical trials are conjunctivitis and blepharitis [30,31]. In observations during the use of the drug outside clinical trials, this complication reaches the level of $38.2 \%$ [26]. The sug-
Skuteczność terapii dupilumabem u dzieci od 6. roku życia, młodzieży i dorosłych

Skuteczność i bezpieczeństwo stosowania dupilumabu w monoterapii lub jednocześnie $\mathrm{z}$ aplikowanymi miejscowo glikokortykosteroidami (GKS) u dorosłych oceniano $\mathrm{w}$ badaniach fazy IIb z randomizacją, prowadzonych metodą podwójnie ślepej próby, kontrolowanych placebo - LIBERTY AD SOLO $1 \mathrm{z}$ udziałem 452 pacjentów, LIBERTY AD SOLO 2 z udziałem 1379 pełnoletnich pacjentów z AZS oraz LIBERTY AD CHRONOS z udziałem 740 pacjentów z trwającym do 52 tygodni AZS [16-19]. Do badań kwalifikowano chorych z wcześniej niewystarczającą odpowiedzią na leki stosowane miejscowo, z ciężkim i umiarkowanym AZS ocenianym na podstawie wyniku ogólnej oceny przez badacza (investigator's global assessment - IGA) $\geq 3$, wskaźnika powierzchni i nasilenia wyprysku (eczema area and severity index - EASI) $\geq 16$ oraz zajętej powierzchni ciała (body surface area - BSA) $\geq 10 \%$. Dupilumab znacząco zmniejszał obiektywne i subiektywne objawy oraz poprawiał jakość życia pacjentów z umiarkowanym i ciężkim AZS. Obserwowano redukcję wyniku w skali SCORAD i EASI-75, zmniejszenie nasilenia świądu, lęku lub depresji i zaburzeń snu u dorosłych [16-21]. Lek jest podawany podskórnie (s.c.) w dawce pierwszorazowej $600 \mathrm{mg}$, a następnie co 2 tygodnie $\mathrm{w}$ dawce $300 \mathrm{mg}$ s.c.

W grupie młodzieży powyżej 12. roku życia zrandomizowano 251 pacjentów w wieku średnio 14,5 $\pm 1,7$ roku. W większości mieli oni inne towarzyszące choroby alergiczne, takie jak astma, alergia pokarmowa, alergiczny nieżyt nosa. Dupilumab znacząco zmniejszył objawy przedmiotowe i podmiotowe oraz poprawił jakość życia młodzieży z umiarkowaną do ciężkiej postaci AZS przy akceptowalnym profilu bezpieczeństwa. Skuteczność leku w przypadku podawania co 2 tygodnie była zdecydowanie lepsza niż w przypadku podawania co 4 tygodnie [22]. Wyniki uzyskano i oceniano po 16 tygodniach trwania leczenia. Lek podawano podskórnie $\mathrm{w}$ dawce $200 \mathrm{mg}$ dzieciom o masie ciała < $60 \mathrm{~kg}$ lub $300 \mathrm{mg}$ o masie ciała $\geq 60 \mathrm{~kg}$ co 2 tygodnie lub $300 \mathrm{mg}$ co 4 tygodnie.

Dostępne są dane z III fazy badania klinicznego leczenia dupilumabem $z$ towarzyszącym leczeniem miejscowym GKS (mGKS) u dzieci w wieku 6-11 lat z ciężkim AZS nieadekwatnie kontrolowanym leczeniem miejscowym [23]. Do 16-tygodniowego badania włączono 367 dzieci. Dupilumab okazał się skuteczny i poprawiał jakość życia pacjentów w tej grupie wiekowej. Optymalna dawka pod względem skuteczności i działań niepożądanych to $300 \mathrm{mg}$ co 4 tygodnie dla dzieci o masie $<30 \mathrm{~kg}$ oraz $200 \mathrm{mg}$ co 2 tygodnie dla dzieci o masie $\geq 30 \mathrm{~kg}$ [23]. Dane z rejestrów i opisy pacjentów leczonych dupilumabem w rzeczywistości, poza badaniami klinicznymi, wskazują na porównywalne wyniki z uzyskanymi w badaniach klinicznych [24-29]. 
gested treatment is the use of artificial tears, drops with topical GCS (fluorometholone $0.1 \%$ ), topical calcineurin inhibitors ( $\mathrm{tCI}$ ) applied to the eyelids in moderate cases, and eye drops or ointments containing cyclosporin or tacrolimus in severe forms [31, 32].

Most cases of conjunctivitis are transient and can be successfully treated by continuing the therapy with dupilumab [29]. In terms of rates of infection, it was found that it was similar in adult patients receiving dupilumab and placebo. Dupilumab did not increase the risk of infection, nasopharyngitis, or upper respiratory tract infection, and the systemic use of antiinfective agents was lower in the dupilumab group. Fewer serious/severe bacterial infections and other non-herpetic skin infections were observed among patients using dupilumab [33]. Among the side effects with long-term use of dupilumab, paradoxical erythema of the face, décolleté and neck, usually after 10-39 weeks of using dupilumab, has been reported $[34,35]$. In the group of adolescents $>12$ years of age treated with dupilumab, a higher percentage of conjunctivitis and reactions at the injection site and lower rates of non-herpetic skin infections were observed [21]. Children with severe AD, aged 6-11 treated with dupilumab presented more frequent conjunctivitis and injection site reactions than the placebo group [23]. More research is needed in the pediatric group.

\section{Laboratory tests, monitoring during dupilumab therapy}

According to the evaluation of the results of available clinical trials conducted in the adult group, there is no need for laboratory monitoring during dupilumab therapy [36]. However, before and during dupilumab therapy (after 16 weeks and then every 3 months), we suggest performing basic tests (complete blood count with smear, AST, ALT, creatinine, urea, $\mathrm{CRP}$ ). Before starting the therapy, we additionally recommend a pregnancy test in women of childbearing age, ECG and chest $\mathrm{X}$-ray examinations (table 1 ).

Data on long-term safety in children and adolescents are time-limited and the size of the pediatric group indicates a need to extend the research in these age groups.

Safety of long-term dupilumab therapy in children from 6 years of age, adolescents and adults

Long-term safety of up to 3 years of use of dupilumab has been established for adults $[37,38]$. In the group of children aged 12-17 years, safety data covers up to 52 weeks of treatment with dupilumab [39]. In this group, as well as in the group of 6-11-yearolds there are currently no results of studies lasting more than 1 year $[23,39]$.
Działania niepożądane podczas terapii dupilumabem u dzieci od 6. roku życia, młodzieży i dorosłych

Najczęstszym działaniem niepożądanym, obserwowanym u 22,1\% dorosłych pacjentów leczonych dupilumabem $w$ badaniach klinicznych jest zapalenie spojówek i zapalenie powiek [30,31]. Powikłanie to $\mathrm{w}$ obserwacjach dotyczących stosowania leku poza badaniami klinicznymi występuje u 38,2\% pacjentów [26]. Sugerowanym leczeniem są stosowanie sztucznych łez, krople z mGKS (fluorometolon 0,1\%), miejscowe inhibitory kalcyneuryny (mIK) aplikowane na powieki w umiarkowanych przypadkach oraz krople do oczu lub maści zawierające cyklosporynę lub takrolimus w ciężkich postaciach [31, 32].

Większość przypadków zapalenia spojówek ma charakter przejściowy i można je z powodzeniem leczyć, kontynuując terapię dupilumabem [29]. Wskaźniki infekcji u dorosłych stosujących dupilumab i placebo okazały się podobne. Dupilumab nie zwiększał ryzyka infekcji, zapalenia nosogardzieli i zakażenia górnych dróg oddechowych, a ogólnoustrojowe stosowanie leków przeciwinfekcyjnych było mniejsze w grupie leczonej dupilumabem. Wśród pacjentów stosujących dupilumab obserwowano mniej poważnych lub ciężkich zakażeń bakteryjnych i innych nieopryszczkowych zakażeń skóry [33]. Spośród działań niepożądanych przy długotrwałym stosowaniu dupilumabu stwierdzono pojawianie się paradoksalnego rumienia twarzy, dekoltu i szyi, zwykle po 10-39 tygodniach [34, 35]. W grupie młodzieży powyżej 12. roku życia leczonej dupilumabem obserwowano większy odsetek zapalenia spojówek i odczynów w miejscu podania leku oraz niższe wskaźniki nieopryszczkowych infekcji skóry [21]. U dzieci z ciężkim AZS w wieku 6-11 lat leczonych dupilumabem częściej występowały zapalenie spojówek oraz reakcje w miejscu wstrzyknięcia niż w grupie przyjmującej placebo [23]. Konieczne są dalsze badania $\mathrm{w}$ grupie pediatrycznej.

Badania laboratoryjne, monitorowanie w trakcie terapii dupilumabem

Jak wynika z oceny rezultatów dostępnych badań klinicznych prowadzonych u dorosłych, w trakcie terapii dupilumabem nie ma potrzeby monitorowania laboratoryjnego [36]. Jednak przed terapią i podczas leczenia dupilumabem (po 16 tygodniach i potem co 3 miesiące) sugeruje się wykonywanie badań podstawowych (morfologia krwi z rozmazem, AspAT, AlAT, kreatynina, mocznik, CRP). Przed rozpoczęciem terapii dodatkowo zaleca się przeprowadzenie próby ciążowej u kobiet $\mathrm{w}$ wieku rozrodczym, badania elektrokardiograficznego (EKG) oraz rentgenograficznego (RTG) klatki piersiowej (tab. 1). 
Table I. Diagnostic procedures before and during the treatment with dupilumab

\begin{tabular}{l}
\hline Procedures before start of the therapy with dupilumab: \\
\hline I. General health assessment based on the medical history \\
\hline 2. Assessment of symptoms intensity with the EASI score \\
\hline 3. Blood cell count with smear \\
\hline 4. Clinical chemistry: creatinine, urea, CRP, transaminases (ALT, \\
AST) \\
\hline 5. X-ray of the chest \\
\hline 6. ECG \\
\hline 7. Pregnancy test in women of childbearing potential \\
\hline Procedures after I6 weeks of the therapy, and then every \\
3 months \pm 7 days: \\
\hline I. General health assessment based on the medical history \\
\hline 2. Assessment of symptoms intensity with the EASI score \\
3. Blood cell count with smear \\
4. Clinical chemistry: creatinine, urea, CRP, transaminases (ALT, \\
AST)
\end{tabular}

Dupilumab combined with other drugs used in atopic dermatitis

Dupilumab should be combined with the daily use of emollients and, if necessary, may be combined with topical anti-inflammatory drugs [40].

\section{RECOMMENDATION}

The use of dupilumab is recommended in patients from 12 years of age with moderate to severe AD (EASI $\geq 16$, SCORAD $\geq 25$ ) who do not respond to local treatment. The duration of therapy depends on the resolution of the disease and the decision of the treating physician. Dupilumab may be self-administered subcutaneously by the patient or his caregivers at home (table 2).

If there is no improvement after 16 weeks of dupilumab use (assessed as not achieving at least a 50\% reduction in the EASI score), treatment with this drug should be discontinued.

\section{OTHER BIOLOGICAL DRUGS - MONOCLONAL BODIES IN THE TREATMENT OF ATOPIC DERMATITIS}

Randomized, double-blind, placebo-controlled clinical trials are currently underway to evaluate the efficacy and safety of other biologics in adult patients with mild and severe AD. There are test results for monoclonal antibodies such as: lebrikizumab (antiIL-13), tralokinumab, nemolizumab (anti-IL-31Ra),
Tabela I. Badania diagnostyczne przed leczeniem i podczas leczenia dupilumabem

\begin{tabular}{l}
\hline Badania przed rozpoczęciem terapii dupilumabem: \\
\hline I. Ocena ogólnego stanu zdrowia pacjenta na podstawie \\
wywiadu \\
\hline 2. Ocena nasilenia objawów choroby wg EASI \\
\hline 3. Morfologia krwi z rozmazem \\
\hline 4. Badania biochemiczne: stężenie kreatyniny, mocznika, białka \\
C-reaktywnego (CRP), transaminaz (AIAT, AspAT) \\
\hline 5. RTG klatki piersiowej \\
\hline 6. EKG \\
\hline 7. Próba ciążowa u kobiet w wieku rozrodczym \\
\hline Badania po I6 tygodniach terapii, a następnie co 3 miesiące \\
土7 dni: \\
\hline I. Ocena ogólnego stanu zdrowia pacjenta na podstawie \\
wywiadu \\
\hline 2. Ocena nasilenia objawów choroby wg EASI \\
\hline 3. Morfologia krwi z rozmazem \\
\hline 4. Badania biochemiczne: stężenie kreatyniny, mocznika, CRP, \\
transaminaz (AlAT, AspAT)
\end{tabular}

Dane dotyczące długoterminowego bezpieczeństwa u dzieci i młodzieży są ograniczone czasowo, a liczebność grupy pediatrycznej wskazuje na potrzebę poszerzenia badań w tych grupach wiekowych.

Bezpieczeństwo długoterminowej terapii dupilumabem u dzieci od 6. roku życia, młodzieży i dorosłych

Długoterminowe bezpieczeństwo do 3 lat stosowania dupilumabu zostało określone dla dorosłych $[37,38]$. U dzieci w wieku 12-17 lat dane dotyczące bezpieczeństwa obejmują czas do 52 tygodni leczenia dupilumabem [39]. Zarówno w tej grupie, jak i w grupie 6-11 lat brakuje obecnie wyników badań trwających powyżej roku $[23,39]$.

Dupilumab w połączeniu z innymi lekami stosowanymi w atopowym zapaleniu skóry

Dupilumab powinien być łączony z codziennym stosowaniem emolientów i w razie potrzeby miejscowych leków przeciwzapalnych [40].

\section{REKOMENDACJA}

Stosowanie dupilumabu zaleca się pacjentom od 12. roku życia z umiarkowanym i ciężkim AZS (EASI $\geq 16$, SCORAD $\geq 25$ ), którzy nie reagują na leczenie miejscowe. Czas terapii zależy od ustępowania choroby i decyzji lekarza leczącego. Dupilumab może być samodzielnie aplikowany podskórnie przez pacjenta lub jego opiekunów w warunkach domowych (tab. 2). 
Table 2. Dosage of dupilumab for subcutaneous administration to patients with atopic dermatitis

\begin{tabular}{|c|c|c|}
\hline Patients & Initial dose & $\begin{array}{l}\text { Subsequent doses } \\
\text { (every } 2 \text { weeks) }\end{array}$ \\
\hline \multicolumn{3}{|c|}{ Adolescents from 12 to 17 years: } \\
\hline Below $60 \mathrm{~kg}$ & $\begin{array}{c}400 \text { mg (two s.c. } \\
\text { injections a' } 200 \text { mg) }\end{array}$ & $200 \mathrm{mg}$ \\
\hline $60 \mathrm{~kg}$ or more & $\begin{array}{c}600 \text { mg (two s.c. } \\
\text { injections a' } 300 \text { mg) }\end{array}$ & $300 \mathrm{mg}$ \\
\hline Adults & $\begin{array}{c}600 \text { mg (two s.c. } \\
\text { injections a' } 300 \text { mg) }\end{array}$ & $300 \mathrm{mg}$ \\
\hline
\end{tabular}

fezakinumab (anti-IL-22), etokimab (anti-IL-33) and tezepelumab (anti-TSLP).

\section{Lebrikizumab}

Lebrikizumab is an IL-13 binding monoclonal antibody. A randomized, placebo-controlled phase II clinical trial enrolled 209 adult patients with severe to moderate AD in whom tGCSs were ineffective. The drug efficacy and safety were assessed after 12 weeks. The drug was administered to patients at the dose of 125 mg every 4 weeks - subcutaneously, and at the same time the use of tGCSs was allowed. Lebrikizumab led to significant clinical improvement and was well tolerated [41].

\section{Tralokinumab}

Tralokinumab is an IL-13 binding monoclonal antibody. The results of the phase IIb clinical trial were published in 2019. The study included 204 adult patients with moderate and severe AD. The treatment was combined with tGCSs. Results summarized after 12 weeks of therapy indicated that the treatment with tralocanumab was associated with an early and sustained improvement in AD symptoms with an acceptable safety and drug tolerance profile [42].

\section{Nemolizumab}

Given the pathogenesis of pruritus in AD, nemolizumab - an antibody directed against the IL-31 receptor - gave hope for improvement in this persistent symptom.

In a phase II study in 264 adult patients with severe and moderate $\mathrm{AD}$ who were not treated with tGCSs, 12 weeks of nemolizumab therapy brought a significant reduction in pruritus in treated patients. However, a limited number of patients enrolled in the study and a short evaluation period (12 weeks at the summary stage) did not allow the authors to draw conclusions about adverse effects [43]. Another phase IIb study with nemolizumab $10 \mathrm{mg}$, $30 \mathrm{mg}$ and $90 \mathrm{mg}$ administered subcutaneously every 4 weeks with 226 patients was summarized after 24 weeks of
Tabela 2. Dawkowanie dupilumabu do podania podskórnego u pacjentów z atopowym zapaleniem skóry

\begin{tabular}{|c|c|c|}
\hline Pacjenci & Dawka początkowa & $\begin{array}{l}\text { Kolejne dawki } \\
\text { (co } 2 \text { tygodnie) }\end{array}$ \\
\hline \multicolumn{3}{|c|}{ Młodzież od 12. do 17. roku życia: } \\
\hline Poniżej 60 kg & $\begin{array}{c}400 \text { mg (dwa wstrzyknięcia } \\
\text { s.c. po } 200 \text { mg) }\end{array}$ & $200 \mathrm{mg}$ \\
\hline $\begin{array}{l}60 \text { kg lub } \\
\text { więcej }\end{array}$ & $\begin{array}{c}600 \text { mg (dwa wstrzyknięcia } \\
\text { s.c. po } 300 \text { mg) }\end{array}$ & $300 \mathrm{mg}$ \\
\hline Dorośli & $\begin{array}{c}600 \text { mg (dwa wstrzyknięcia } \\
\text { s.c. po } 300 \text { mg) }\end{array}$ & $300 \mathrm{mg}$ \\
\hline
\end{tabular}

W przypadku braku poprawy po 16 tygodniach stosowania dupilumabu (ocenianej jako nieuzyskanie co najmniej 50\% redukcji wskaźnika EASI) należy przerwać leczenie tym lekiem.

\section{INNE LEKI BIOLOGICZNE - PRZECIWCIAŁA MONOKLONALNE W TERAPII ATOPOWEGO ZAPALENIA SKÓRY}

Aktualnie trwają badania kliniczne $\mathrm{z}$ randomizacją prowadzone metodą podwójnie ślepej próby, kontrolowane placebo, które oceniają skuteczność i bezpieczeństwo innych leków biologicznych u dorosłych pacjentów z umiarkowanym i ciężkim AZS. Dostępne są wyniki badań dla przeciwciał monoklonalnych, takich jak: lebrikizumab (anty-IL-13), tralokinumab, nemolizumab (anty-IL-31Ra), fezakinumab (anty-IL22), etokimab (anty-IL-33) i tezepelumab (anty-TSLP).

\section{Lebrikizumab}

Lebrikizumab to przeciwciało monoklonalne wiążące IL-13. Do badania klinicznego fazy II $\mathrm{z}$ randomizacją kontrolowanego placebo włączono 209 dorosłych pacjentów z ciężkim i umiarkowanym AZS, u których mGKS okazały się nieskuteczne. Skuteczność i bezpieczeństwo leku oceniono po 12 tygodniach. Dawkę $125 \mathrm{mg}$ lebrikizumabu podawano pacjentom co 4 tygodnie podskórnie i jednocześnie dozwolone było stosowanie mGKS. Lebrikizumab pozwalał na uzyskanie znaczącej poprawy klinicznej i był dobrze tolerowany [41].

\section{Tralokinumab}

Tralokinumab to przeciwciało monoklonalne wiążące IL-13. Wyniki badania klinicznego fazy IIb opublikowano w 2019 r. Badaniem objęto 204 dorosłych chorych z umiarkowanym i ciężkim AZS. Lek stosowano w skojarzeniu z mGKS. Wyniki podsumowane po 12 tygodniach terapii wskazały, że leczenie tralokinumabem było związane z wczesną i trwałą poprawą objawów AZS przy akceptowalnym profilu bezpieczeństwa i tolerancji leku [42]. 
treatment. Nemolizumab produced a rapid and sustained improvement in cutaneous inflammation and itching with maximum efficacy seen with the $30 \mathrm{mg}$ dose. The safety profile of nemolizumab was assessed as acceptable [44]. The drug has also been evaluated in a long-term study in 264 patients with moderate to severe AD. Nemolizumab used for up to 64 weeks was effective and well tolerated. Similar responses in improvement of EASI-75 score were observed in the treated and placebo groups. However, the pruritus was significantly reduced in patients treated with the active drug [45].

\section{Fezakinumab}

Fezakinumab, an anti-IL-22 antibody, was evaluated in a phase IIa clinical trial in 60 patients with moderate to severe AD not controlled with tGCSs. The study ran for 20 weeks and results were summarized at week 12 . Fezakinumab was well tolerated and provided a long-term clinical improvement after the last drug administration [46].

\section{Etokimab}

Etokimab is an anti-IL-33 monoclonal IgG1 antibody. A phase Ila study was conducted in 12 adult patients with moderate to severe AD. Patients received etokimab once. Rapid and sustained clinical improvement was observed. Eighty-three percent of patients reached EASI50, and 33\% reached EASI75, with a reduction in peripheral blood eosinophils on day 29 after dosing. These results confirm the role of IL-33 in modulation of the inflammatory cascade in atopic skin and confirm the therapeutic potential of IL-33 in the treatment of AD [47].

\section{Tezepelumab}

Tezepelumab is a monoclonal antibody directed against thymic stromal lymphopoietin (anti-TSLP). Considering the role of TSLP in the pathogenesis of $\mathrm{AD}$, this cytokine derived from damaged keratinocytes raises high hopes as a therapeutic target. Results of the phase IIa study involving 113 patients with moderate to severe AD who used tGCSs along with the study drug were summarized in weeks 12 and 16 of treatment with a subcutaneous dose of $280 \mathrm{mg}$ of the drug administered every 2 weeks. EASI50 was achieved by more patients treated with tezepelumab than with placebo. However, these differences were not statistically significant, although an increase in the proportion of responders at the week 16 of the study was observed [48].

\section{OX40 molecule antagonists}

OX40 is a costimulatory receptor on activated T cells (CD4). The fully human anti-OX40 monoclonal

\section{Nemolizumab}

Ze względu na patogenezę świądu w AZS nemolizumab, przeciwciało skierowane przeciwko receptorowi IL-31, dawał nadzieję na poprawę w zakresie tego uporczywego objawu.

W badaniu fazy II obejmującym 264 dorosłych pacjentów z ciężkim i umiarkowanym AZS, które nie poddawało się leczeniu mGKS, po 12 tygodniach terapii nemolizumabem wykazano znaczące złagodzenie świądu. Ograniczona liczba włączonych do badania pacjentów oraz krótki czas oceny (12 tygodni na etapie podsumowania wyników) nie pozwoliły jednak autorom wnioskować na temat działań niepożądanych [43]. Kolejne badanie fazy IIb z nemolizumabem w dawce $10 \mathrm{mg}$, $30 \mathrm{mg}$ i $90 \mathrm{mg}$ podawanym podskórnie co 4 tygodnie 226 pacjentom podsumowano po 24 tygodniach leczenia. Nemolizumab powodował szybką i trwałą poprawę skórnych objawów zapalnych i świądu z maksymalną skutecznością obserwowaną przy dawce $30 \mathrm{mg}$. Profil bezpieczeństwa nemolizumabu oceniono jako akceptowalny [44]. Lek ten poddano też długoterminowej ocenie wśród 264 pacjentów z umiarkowanym i ciężkim AZS. Nemolizumab stosowany przez 64 tygodnie okazał się skuteczny i był dobrze tolerowany. Obserwowano podobne odpowiedzi w zakresie poprawy EASI-75 w grupie leczonej i placebo, niemniej znacząco zmniejszył się świąd u chorych, którym podawano lek [45].

\section{Fezakinumab}

Fezakinumab, przeciwciało przeciw IL-22, oceniano w badaniu klinicznym fazy IIa u 60 pacjentów z umiarkowanym i ciężkim AZS niekontrolowanym mGKS. Badanie trwało 20 tygodni, a wyniki podsumowano w 12. tygodniu. Fezakinumab był dobrze tolerowany, dawał długotrwałą poprawą kliniczną po ostatnim podaniu [46].

\section{Etokimab}

Etokimab to przeciwciało monoklonalne IgG1 anty-IL-33. Badanie fazy IIa objęło 12 dorosłych pacjentów z AZS w postaci od umiarkowanej do ciężkiej. Pacjenci otrzymali jednorazowo etokimab. Obserwowano szybką i trwałą poprawę kliniczną, przy czym 83\% chorych osiągnęło EASI50, a 33\% EASI75, ze zmniejszeniem liczby eozynofilów we krwi obwodowej w 29. dniu po podaniu leku. Wyniki te potwierdzają rolę IL-33 w modulowaniu kaskady zapalnej w skórze atopowej i potwierdzają jej terapeutyczny potencjał w leczeniu AZS [47].

\section{Tezepelumab}

Tezepelumab to przeciwciało monoklonalne przeciwko limfopoetynie zrębu grasiczego (anti-TSLP). Ze 
antibody was tested under the names KHK4083 and GBR830.

A phase I study evaluated the pharmacokinetics and immunogenicity of KHK4083 in 22 Japanese patients with moderate and severe AD [22]. The drug was administered at the dose of $10 \mathrm{mg} / \mathrm{kg}$ intravenously on days 1, 15 and 29 and patients were followed up to day 155. Multiple intravenous infusions of KHK4083 had an acceptable security profile. After the end of treatment with KHK4083, a sustained improvement in AD symptoms was observed [49]. It is interesting whether these results can be extrapolated to the European population in the face of hypotheses/theories of differentiation of AD endotypes also in the ethnic context. GBR830 was also evaluated among US patients with moderate to severe AD in a phase 2 a study that enrolled 64 patients. More than 40 people received the drug on days 1 and 29, and in 40 cases its effect was assessed in histopathological preparations. Two doses of GBR830 given 4 weeks apart were well tolerated and induced resolution of tissue and clinical changes by day 71 , confirming the therapeutic potential of this drug [50].

Results of studies with the monoclonal bodies described above refer to the phase II in adults. A clear limitation is the low size of study groups. Results of the phase III of this research may be expected soon.

\section{Agonists and antagonists of small molecules}

JAK-STAT inhibitors are a group of drugs that have been intensely studied in AD in recent years. These drugs are less selective than monoclonal bodies. They block the activation of Janus kinases, translocating the signal to the cell nucleus and, consequently, the transcription of many pro-inflammatory cytokines. Results of research completed so far are promising. These drugs are mainly used orally or topically.

\section{Abrocitinib}

Abrocitinib is a selective JAK1 inhibitor. A phase IIb, randomized, double-blind, placebo-controlled (RDBPC) study was conducted in 267 adult patients with moderate to severe AD with insufficient response or contraindication to topical treatment. The results of the study, summarized after 12 weeks of treatment, showed that abrocitinib administered orally once daily was effective and well tolerated for short term use in adults with moderate to severe AD. However, additional studies were necessary to assess the long-term efficacy and safety of the drug [51]. This year, the results of the phase III JADE study were published [52]. Three hundred and eighty-seven adolescent patients from 12 years of age and adults with moderate and severe atopic względu na rolę TSLP w patogenezie AZS cytokina ta, wywodząca się z uszkodzonych keratynocytów, budzi duże nadzieje jako cel terapeutyczny. Wyniki badania fazy IIa obejmującego 113 pacjentów z umiarkowanym i ciężkim AZS, którzy jednocześnie z lekiem badanym stosowali mGKS, podsumowano w 12. i 16. tygodniu trwania leczenia dawką $280 \mathrm{mg}$ podawaną podskórnie co 2 tygodnie. EASI50 osiągnęło więcej pacjentów leczonych tezepelumabem niż placebo, jednak nie były to różnice statystycznie istotne, choć obserwowano wzrost odsetka odpowiadających w 16. tygodniu obserwacji [48].

\section{Antagoniści cząsteczki OX40}

OX40 to receptor kostymulujący na aktywowanych limfocytach T (CD4). W pełni ludzkie przeciwciało monoklonalne anty-OX40 badano pod nazwą KHK4083 oraz GBR830.

W badaniu fazy I oceniano farmakokinetykę i immunogenność KHK4083 u 22 japońskich pacjentów z umiarkowanym i ciężkim AZS. Lek podawano w dawce $10 \mathrm{mg} / \mathrm{kg}$ m.c. dożylnie w dniach 1., 15. i 29., a chorych obserwowano do dnia 155. Wielokrotny wlew dożylny KHK4083 miał akceptowalny profil bezpieczeństwa. Po zakończeniu leczenia KHK4083 stwierdzono utrzymującą się poprawę objawów AZS [49]. Zastanawiające jest, czy wyniki te można ekstrapolować na populację europejską w obliczu hipotez lub teorii zróżnicowania endotypów AZS także w kontekście etnicznym. GBR830 oceniano też wśród pacjentów amerykańskich z umiarkowanym i ciężkim AZS w badaniu fazy IIa, do którego włączono 64 osoby. Lek w dniu 1. i 29. otrzymało ponad 40 pacjentów, a w 40 przypadkach jego działanie oceniono w preparatach histopatologicznych. Dwie dawki GBR830 podane w odstępie 4 tygodni były dobrze tolerowane i indukowały ustępowanie zmian tkankowych i klinicznych do dnia 71., co potwierdza potencjał terapeutyczny tego leku [50].

Wyniki badań z wyżej opisanymi przeciwciałami monoklonalnymi dotyczą fazy II u osób dorosłych. Wyraźnym ograniczeniem jest mała liczebność badanych grup. Niebawem można się spodziewać wyników fazy III tych badań.

\section{Agoniści i antagoniści małych cząsteczek}

Inhibitory JAK-STAT to grupa leków intensywnie badanych w AZS w ostatnich latach. Działają one mniej wybiórczo niż przeciwciała monoklonalne. Blokują aktywację kinaz janusowych, przemieszczanie sygnału do jądra komórkowego, a także transkrypcję wielu cytokin prozapalnych. Wyniki dotychczasowych badań są obiecujące. Leki te stosuje się głównie doustnie lub miejscowo. 
dermatitis used the drug at the dose of $100 \mathrm{mg}$ or $200 \mathrm{mg}$. The study is still ongoing, but results summarized after 12 weeks of therapy showed the clinical effect of EASI75 for both doses of the drug. Oral once daily monotherapy with abrocitinib was effective and well tolerated in adolescents and adults with moderate to severe AD [52].

\section{Baricitinib}

Baricitinib is a selective inhibitor of JAK1 and JAK2. A phase II study, RDBPC, was conducted in 124 adult patients with moderate to severe AD. The drug at the dose of $4 \mathrm{mg}$ and $2 \mathrm{mg}$ was used orally with the possibility of simultaneous application of tGCSs. After 16 weeks of the study, a significant reduction in the severity of clinical symptoms of $\mathrm{AD}$ and an improvement in the quality of life was achieved. It is worth noting that improvement in clinical symptoms, including reduction of itching, was noted already in the first week of treatment in patients taking the drug at the dose of $4 \mathrm{mg}$. No serious adverse events were observed [53]. Results of the phase III study have been published this year. The BREEZE-AD1 arm included 624 patients, and the BREEZE-AD2 arm included 615 patients with moderate and severe AD. Results of the study were collected after 16 weeks of treatment with baricitinib at doses of $1 \mathrm{mg}, 2 \mathrm{mg}$ and $4 \mathrm{mg}$. Baricitinib improved clinical signs and symptoms in patients with moderate to severe AD and produced a rapid reduction of pruritus. The drug's safety profile was consistent with previous clinical studies with baricitinib in AD. The study is ongoing and new summaries of further results should be expected soon [54].

\section{Upadacitinib}

Upadacitinib is a selective JAK1 inhibitor. Results of the phase IIb study, planned for 88 weeks in adult patients with moderate and severe AD, showed a significant effect of the drug on the reduction of itch from day 2 of the therapy [55]. A parallel study involving 167 adult patients with moderate to severe AD reported drug efficacy assessed using the EASI and NRS (pruritus severity scale), IGA scales at all doses, i.e. $7.5 \mathrm{mg}, 15 \mathrm{mg}$ and $30 \mathrm{mg}$ after 16 weeks of therapy. A dose-response relationship was observed for the efficacy of Spadacitinib: $30 \mathrm{mg}$ once daily produced the greatest clinical benefit. No dose limiting toxicity was observed [56].

\section{Tofacitinib}

Tofacitinib is a non-selective JAK1/3 inhibitor. It was administered orally to 6 patients with moderate and severe atopic dermatitis, causing reduction of symptoms measured by the SCORAD scale without

\section{Abrocytynib}

Abrocytynib to selektywny inhibitor JAK1. Badanie fazy IIb, z randomizacją, podwójnie zaślepione, kontrolowane placebo (RDBPC) przeprowadzono wśród 267 dorosłych pacjentów z umiarkowanym i ciężkim AZS z niewystarczającą odpowiedzią lub przeciwwskazaniem do leczenia miejscowego. Wyniki podsumowane po 12 tygodniach leczenia wykazały, że abrocytynib podawany doustnie raz dziennie był skuteczny i dobrze tolerowany w krótkotrwałym stosowaniu u dorosłych z umiarkowanym do ciężkiego AZS. Konieczne były jednak dodatkowe badania, aby ocenić długoterminową skuteczność i bezpieczeństwo leku [51]. W tym roku opublikowano wyniki badania fazy III JADE [52]. Trzystu osiemdziesięciu siedmiu pacjentów od 12. roku życia z umiarkowanym i ciężkim AZS stosowało lek w dawce 100 mg lub 200 mg. Badanie trwa nadal, ale wyniki podsumowane już po 12 tygodniach terapii wykazały efekt kliniczny EASI75 przy obu dawkach leku. Monoterapia doustnym abrocytynibem raz na dobę była skuteczna i dobrze tolerowana u młodzieży i dorosłych z umiarkowanym do ciężkiego AZS [52].

\section{Baricytynib}

Baricytynib jest selektywnym inhibitorem JAK1 i JAK2. Badanie fazy II RDBPC przeprowadzono u 124 dorosłych pacjentów z umiarkowanym i ciężkim AZS. Lek w dawce $4 \mathrm{mg}$ i 2 mg stosowano doustnie z możliwością jednoczesnego aplikowania mGKS. Po 16 tygodniach badania osiągnięto znaczne zmniejszenie nasilenia objawów klinicznych i poprawę jakości życia. Warto zauważyć, że poprawę w zakresie objawów klinicznych, w tym redukcję świądu, stwierdzono już w 1. tygodniu leczenia u pacjentów przyjmujących lek w dawce $4 \mathrm{mg}$. Nie obserwowano poważnych zdarzeń niepożądanych [53]. Wyniki badania fazy III opublikowano w bieżącym roku. W ramieniu BREEZE-AD1 wzięło udział 624 pacjentów, a w BREEZE-AD2 615 pacjentów z umiarkowanym i ciężkim przebiegiem AZS. Wyniki zebrano po 16 tygodniach terapii baricytynibem w dawce $1 \mathrm{mg}, 2 \mathrm{mg}$ i $4 \mathrm{mg}$. Lek poprawił kliniczne objawy przedmiotowe i podmiotowe u pacjentów z umiarkowanym i ciężkim AZS i powodował szybkie zmniejszenie świądu. Profil bezpieczeństwa był zgodny z wcześniejszymi wynikami badań klinicznych baricytynibu w AZS. Badanie trwa i należy spodziewać się nowych podsumowań wyników w niedługim czasie [54].

\section{Upadacytynib}

Upadacytynib to selektywny inhibitor JAK1. Wyniki badania fazy IIb zaplanowanego na 88 tygodni u pacjentów dorosłych $\mathrm{z}$ umiarkowanym i ciężkim AZS potwierdziły znaczący wpływ leku na redukcję 
any adverse effects for up to 29 weeks of treatment, and it was applied topically in the form of $2 \%$ ointments [57, 58]. 69 patients with mild to moderate AD were enrolled in the phase IIa study. Results after 4 weeks of topical therapy showed a much greater clinical efficacy of the drug than placebo with an early onset of action (reduction of itch observed after 2 days of therapy) [58].

\section{Ruxolitinib (RUX)}

The efficacy and safety of ruxolitinib cream (a selective JAK1 and JAK2 inhibitor) at concentrations ranging from $0.15 \%$ to $1.5 \%$ was assessed in randomized, controlled phase II clinical trials of 307 adult patients with mild to moderate AD. Pruritus disappeared rapidly within 36 hours of treatment, quality of life improved with a good drug tolerance [59].

\section{Delgocitinib}

Delgocitinib is an inhibitor of JAK $1 / 2 / 3$ and TYK2. Results of the phase III study in 158 Japanese patients from 16 years of age with moderate to severe $A D$ are available. $0.5 \%$ delgocitinib ointment used over a period of 28 weeks was effective and well tolerated [60]. An earlier phase II study in 327 adult patients with moderate to severe adult AD tested the drug at concentrations of $0.25 \%, 0.5 \%, 1 \%, 3 \%$ of the ointment applied twice a day. Results showed a significant and rapid improvement in objective clinical symptoms and pruritus severity with a favorable safety profile [61]. Similarly, in the phase II study conducted in a group of 103 children aged 2 to 15 years with the use of delgocitinib at concentrations of $0.25 \%$ and $0.5 \%$, twice a day, an improvement in signs and symptoms, and good drug tolerance were demonstrated [62].

\section{Cerdulatinib and gusacitinib}

Cerdulatinib, a selective JAK and SYK (spleen tyrosine kinase) inhibitor, is currently in the phase II clinical trials using $0.4 \%$ topical gel and shows a reduction in clinical symptoms measured using the EASI scale [63].

Gusacitinib is another JAK/SYK kinase inhibitor in the phase $\mathrm{Ib}$ randomized clinical trial. It is used at the oral dose of $20 \mathrm{mg}, 40 \mathrm{mg}$ and $80 \mathrm{mg}$ versus placebo for 4 weeks in 36 patients with moderate to severe AD. Results after 4 weeks of treatment showed high effectiveness and quick onset of action [64].

\section{CONCLUSIONS}

Presented results of studies of new monoclonal antibodies and small molecules appear to be promising, but long-term safety and efficacy studies in larger świądu od 2. dnia terapii [55]. Równoległe badanie z udziałem 167 pacjentów dorosłych z umiarkowanym i ciężkim AZS wykazało skuteczność leku ocenianą przy użyciu skal EASI i NRS (skala nasilenia świądu), IGA we wszystkich stosowanych dawkach, tj. 7,5 mg, $15 \mathrm{mg}$ i $30 \mathrm{mg}$ po 16 tygodniach terapii. W przypadku upadacytynibu obserwowano zależność dawka-odpowiedź: dawka $30 \mathrm{mg}$ raz na dobę przyniosła największe korzyści kliniczne. Nie stwierdzono toksyczności ograniczającej dawkę [56].

\section{Tofacytynib}

Tofacytynib to nieselektywny inhibitor JAK1/3. Podawano go doustnie 6 pacjentom $\mathrm{z}$ umiarkowanym i ciężkim AZS i obserwowano redukcję objawów mierzonych skalą SCORAD bez działań niepożądanych do 29 tygodni leczenia, stosowano go też miejscowo w formie $2 \%$ maści $[57,58]$. Do badania fazy IIa włączono 69 pacjentów z łagodnym i umiarkowanym AZS. Wyniki po 4 tygodniach terapii miejscowej wykazały znacznie większą skuteczność kliniczną leku niż placebo z wczesnym początkiem działania (poprawa w zakresie świądu już po 2 dniach terapii) [58].

\section{Ruksolitynib (RUX)}

Skuteczność i bezpieczeństwo kremu z ruksolitynibem (selektywnym inhibitorem JAK1 i JAK2) w stężeniach od $0,15 \%$ do $1,5 \%$ oceniano w kontrolowanych badaniach klinicznych fazy II z randomizacją wśród 307 pacjentów dorosłych z łagodnym i umiarkowanym AZS. Obserwowano szybkie ustępowanie świądu w czasie 36 godzin leczenia i poprawę jakości życia przy dobrej tolerancji leku [59].

\section{Delgocytynib}

Delgocytynib to inhibitor JAK1/2/3 i TYK2. Dostępne są wyniki badania fazy III prowadzonego u 158 japońskich pacjentów od 16. roku życia z umiarkowanym i ciężkim AZS, u których 0,5\% delgocytynib w maści stosowany przez 28 tygodni był skuteczny i dobrze tolerowany [60]. We wcześniejszym badaniu fazy II wśród 327 pacjentów dorosłych z umiarkowanym i ciężkim AZS sprawdzano lek w stężeniach 0,25\%,0,5\%,1\%,3\% w maści stosowanej 2 razy dziennie. Wyniki wykazały znaczącą i szybką poprawę objawów klinicznych obiektywnych i nasilenia świądu z korzystnym profilem bezpieczeństwa [61]. Podobnie w badaniu fazy II prowadzonym u 103 dzieci w wieku 2-15 lat z zastosowaniem delgocytynibu w stężeniu 0,25\% i 0,5\% 2 razy dziennie wykazano poprawę objawów przedmiotowych i podmiotowych oraz dobrą tolerancję leku [62].

\section{Cerdulatynib i gusacytynib}

Cerdulatynib - selektywny inhibitor JAK i SYK (spleen tyrosine kinase), jest obecnie w trakcie fazy II 
groups of patients are still absent. Considering the complex etiopathogenesis of AD, endotypic and phenotypic differences, the prospect of having modern drugs for topical, oral and parental use in the therapeutic portfolio for both pediatric and adult groups in the near future is encouraging.

Currently, for the treatment of patients from 12 years of age with moderate to severe AD who do not respond to topical treatment, we recommend the use of dupilumab. Treatment should be initiated by physicians experienced in the diagnosis and treatment of $\mathrm{AD}$.

\section{CONFLICT OF INTEREST}

The authors declare no conflict of interest. badań klinicznych z zastosowaniem 0,4\% żelu, które wykazują redukcję objawów klinicznych mierzonych przy użyciu skali EASI [63].

Gusacytynib to kolejny inhibitor kinaz JAK/SYK $\mathrm{w}$ fazie Ib badania klinicznego $\mathrm{z}$ randomizacją. Stosowany był doustnie w dawce $20 \mathrm{mg}, 40 \mathrm{mg}$ i $80 \mathrm{mg}$ vs placebo przez 4 tygodnie u 36 pacjentów z umiarkowanym i ciężkim AZS. Wyniki po 4 tygodniach leczenia wykazały dużą skuteczność oraz szybki początek działania [64].

\section{PODSUMOWANIE}

Przedstawione wyniki badań nowych przeciwciał monoklonalnych i drobnych cząsteczek wydają się obiecujące, ale brakuje jeszcze długoterminowych badań dotyczących bezpieczeństwa i skuteczności potwierdzonej w większych grupach pacjentów. Ze względu na złożoną etiopatogenezę AZS, różnice endotypowe i fenotypowe budująca jest perspektywa posiadania w nieodległej przyszłości w terapeutycznym portfolio nowoczesnych leków do stosowania miejscowego, doustnego i parenteralnego zarówno dla grupy pediatrycznej, jak i osób dorosłych.

Obecnie u pacjentów od 12. roku życia z umiarkowanym i ciężkim AZS, którzy nie reagują na leczenie miejscowe, zaleca się stosowanie dupilumabu. Leczenie powinno być podejmowane przez lekarzy $\mathrm{z}$ doświadczeniem w diagnozowaniu i leczeniu AZS.

\section{KONFLIKT INTERESÓW}

Autorzy nie zgłaszają konfliktu interesów.

\section{References}

\section{Piśmiennictwo}

1. Bylund S., von Kobyletzki L.B., Svalstedt M., Svensson Å.: Prevalence and incidence of atopic dermatitis: a systematic review. Acta Derm Venereol 2020, 100, adv00160.

2. Barbarot S., Auziere S., Gadkari A., Girolomoni G., Puig L., Simpson E.L., et al.: Epidemiology of atopic dermatitis in adults: results from an international survey. Allergy 2018, 73, 1284-1293.

3. Vakharia P.P., Silverberg J.I.: Adult-onset atopic dermatitis: characteristics and management. Am J Clin Dermatol 2019, 20, 771-779.

4. Czarnowicki T., Krueger J.G., Guttman-Yassky E.: Novel concepts of prevention and treatment of atopic dermatitis through barrier and immune manipulations with implications for the atopic march. J Allergy Clin Immunol 2017, 139, 1723-1734.

5. Silverberg J.I., Becker L., Kwasny M., Menter A., Cordoro K.M., Paller A.S.: Central obesity and high blood pressure in pediatric patients with atopic dermatitis. JAMA Dermatol 2015, 151, 144-152.

6. Sun D., Ong P.Y.: Infectious complications in atopic dermatitis. Immunol Allergy Clin North Am 2017, 37, 75-93.

7. Fenner J., Silverberg N.B.: Skin diseases associated with atopic dermatitis. Clin Dermatol 2018, 36, 631-640.

8. Paller A., Jaworski J.C., Simpson E.L., Boguniewicz M., Russell J.J., Block J.K., et al.: Major comorbidities of atopic dermatitis: beyond allergic disorders. Am J Clin Dermatol 2018, 19, 821-838.

9. Silverberg J.I., Simpson E.L.: Association between severe eczema in children and multiple comorbid conditions and increased healthcare utilization. Pediatr Allergy Immunol 2013, 24, 476-486.

10. Paller A.S., Kong H.H., Seed P., Naik S., Scharschmidt T.C., Gallo R.L., et al.: The microbiome in patients with atopic dermatitis. J Allergy Clin Immunol 2019, 143, 26-35.

11. Palmer C.N., Irvine A.D., Terron-Kwiatkowski A.: Common loss-of-function variants of the epidermal barrier protein filaggrin are a major predisposing factor for atopic dermatitis. Nat Genet 2006, 38, 441-446.

12. Weidinger S., Beck L.A., Bieber T., Kabashima K., Irvine A.D.: Atopic dermatitis. Nat Rev Dis Primers 2018, 4, 1. 
13. Noda S., Suárez-Fariñas M., Ungar B.: The Asian atopic dermatitis phenotype combines features of atopic dermatitis and psoriasis with increased Th17 polarization. J Allergy Clin Immunol 2015, 136, 1254-1264.

14. Brunner P.M., Israel A., Zhang N., Leonard A., Wen H.C., Huynh T., et al.: Early-onset pediatric atopic dermatitis is characterized by Th2, Th22, Th17-centered inflammation and lipid alterations. J Allergy Clin Immunol 2018, 141, 2094-2106.

15. Czarnowicki T., He H., Krueger J.G., Guttman-Yassky E.: Atopic dermatitis endotypes and implications for targeted therapeutics. J Allergy Clin Immunol 2019, 143, 1-11.

16. Beck L.A., Thaci D., Hamilton J.D., Graham N.M., Bieber T., Rocklin R., et al.: Dupilumab treatment in adults with moderate-to-severe atopic dermatitis. N Engl J Med 2014, 371, 130-139.

17. Thaci D., Simpson E.L., Beck L.A., Bieber T., Blauvelt A., Papp K., et al.: Efficacy and safety of dupilumab in adults with moderate-to-severe atopic dermatitis inadequately controlled by topical treatments: a randomised, placebo-controlled, dose-ranging phase $2 \mathrm{~b}$ trial. Lancet 2016, 387, 40-52.

18. Thaçi D., Simpson E.L., Deleuran M., Kataoka Y., Chen Z., Gadkari A., et al.: Efficacy and safety of dupilumab monotherapy in adults with moderate-to-severe atopic dermatitis: a pooled analysis of two phase 3 randomized trials (LIBERTY AD SOLO 1 and LIBERTY AD SOLO 2). J Dermatol Sci 2019, 94, 266-275.

19. Blauvelt A., de Bruin-Weller M., Gooderham M., Cather J.C., Weisman J., Pariser D., et al.: Long-term management of moderate-to-severe atopic dermatitis with dupilumab and concomitant topical corticosteroids (LIBERTY AD CHRONOS): a 1-year, randomised, double-blinded, placebo-controlled, phase 3 trial. Lancet 2017, 389, 2287-2303.

20. Simpson E.L., Akinlade B., Ardeleanu M.: Two phase 3 trials of dupilumab versus placebo in atopic dermatitis. N Engl J Med 2017, 376, 1090-1091.

21. Barbarot S., Wollenberg A., Silverberg J.I., Deleuran M., Pellacani G., Armario-Hita J.C., et al.: Dupilumab provides rapid and sustained improvement in SCORAD outcomes in adults with moderate-to-severe atopic dermatitis: combined results of four randomized phase 3 trials. J Dermatolog Treat 2020; doi: 10.1080/09546634.2020.1750550.

22. Simpson E.L., Paller A.S., Siegfried E.C., Boguniewicz M., Sher L., Gooderham M.J., et al.: Efficacy and safety of dupilumab in adolescents with uncontrolled moderate to severe atopic dermatitis: a phase 3 randomized clinical trial. JAMA Dermatol 2019, 156, 44-56.

23. Paller A.S., Siegfried E.C., Thaçi D., Wollenberg A., Cork M.J., Arkwright P.D., et al.: Efficacy and safety of dupilumab with concomitant topical corticosteroids in children 6 to 11 years old with severe atopic dermatitis: a randomized, double-blinded, placebo-controlled phase 3 trial. J Am Acad Dermatol 2020, 83, 1282-1293.

24. Ariëns L.F.M., van der Schaft J., Bakker D.S., Balak D., Romeijn M.L.E., Kouwenhoven T., et al.: Dupilumab is very effective in a large cohort of difficult-to-treat adult atopic dermatitis patients: first clinical and biomarker results from the BioDay registry. Allergy 2020, 75, 116-126.

25. Jang D.H., Heo S.J., Jung H.J., Park M.Y., Seo S.J., Ahn J.: Retrospective study of dupilumab treatment for moderate to severe atopic dermatitis in Korea: efficacy and safety of dupilumab in real-world practice. J Clin Med 2020, 9, 1982.

26. Fargnoli M.C., Esposito M., Ferrucci S., Girolomoni G., Offidani A., Patrizi A. et al.: Real-life experience on effectiveness and safety of dupilumab in adult patients with moderate-to-severe atopic dermatitis. J Dermatol Treat 2019; doi: 10.1080/09546634.2019.1682503.

27. Abraham S., Haufe E., Harder I., Heratizadeh A., Kleinheinz A., Wollenberg A., et al.: Implementation of dupilumab in routine care of atopic eczema: results from the German national registry TREATgermany. Br J Dermatol 2020, 183, 382-384.

28. Faiz S., Giovannelli J., Podevin C., Jachiet M., Bouaziz J.D., Reguiai Z., et al.: Effectiveness and safety of dupilumab for the treatment of atopic dermatitis in a real-life French multicenter adult cohort. J Am Acad Dermatol 2019, 81, 143-151.

29. de Wijs L.E.M., Bosma A.L., Erler N.S., Hollestein L.M., Gerbens L.A.A., Middelkamp-Hup M.A., et al.: Effectiveness of dupilumab treatment in 95 patients with atopic dermatitis: daily practice data. J Dermatol 2020, 182, 418-426.

30. Akinlade B., Guttman-Yassky E., de Bruin-Weller M., Simpson E.L., Blauvelt A., Cork M.J., et al.: Conjunctivitis in dupilumab clinical trials. Br J Dermatol 2019, 181, 459-473.

31. Wollenberg A., Ariens L., Thurau S., van Luijk C., Seegräber M., de Bruin-Weller M.: Conjunctivitis occurring in atopic dermatitis patients treated with dupilumab-clinical characteristics and treatment. J Allergy Clin Immunol Pract 2018, 6, 1778$80 \mathrm{e} 1771$.

32. Thyssen J.P., de Bruin-Weller M.S., Paller A.S., Leshem Y.A., Vestergaard C., Deleuran M., et al.: Conjunctivitis in atopic dermatitis patients with and without dupilumab therapy - international eczema council survey and opinion. J Eur Acad Dermatol Venereol 2019, 33, 1224-1231.

33. Eichenfield L.F., Bieber T., Beck L.A., Simpson E.L., Thaçi D., de Bruin-Weller M., et al.: Infections in dupilumab clinical trials in atopic dermatitis: a comprehensive pooled analysis. Am J Clin Dermatol 2019, 20, 443-456.

34. de Wijs L.E.M., Nguyen N.T., Kunkeler A.C.M., Nijsten T., Damman J., Hijnen D.J.: Clinical and histopathological characterization of paradoxical head and neck erythema in patients with atopic dermatitis treated with dupilumab: a case series. Br J Dermatol 2020, 183, 745-749.

35. Soria A., Du-Thanh A., Seneschal J., Jachiet M., Staumont-Sallé D., Barbarot S.; GREAT Research Group: Development or exacerbation of head and neck dermatitis in patients treated for atopic dermatitis with dupilumab. JAMA Dermatol 2019, 155, 1312-1315.

36. Wollenberg A., Beck L.A., Blauvelt A., Simpson E.L., Chen Z., Chen Q., et al.: Laboratory safety of dupilumab in moderate-to-severe atopic dermatitis: results from three phase III trials (LIBERTY AD SOLO 1, LIBERTY AD SOLO 2, LIBERTY AD CHRONOS). Assessing the need for routine safety testing for patients being treated with dupilumab for moderate-to-severe atopic dermatitis. J Dermatol 2020, 182, e186-e209.

37. Beck L.A., Thaçi D., Deleuran M., Blauvelt A., Bissonnette R., de Bruin-Weller M., et al.: Dupilumab provides favorable safety and sustained efficacy for up to 3 years in an open-label study of adults with moderate-to-severe atopic dermatitis. Am J Clin Dermatol 2020, 21, 567-577. 
38. Deleuran M., Thaçi D., Beck L.A., de Bruin-Weller M., Blauvelt A., Forman S., et al.: Dupilumab shows long-term safety and efficacy in patients with moderate to severe atopic dermatitis enrolled in a phase 3 open-label extension study. J Am Acad Dermatol 2020, 82, 377-388.

39. Cork M.J., Thaçi D., Eichenfield L.F., Arkwright P.D., Hultsch T., Davis J.D., et al.: Dupilumab in adolescents with uncontrolled moderate-to-severe atopic dermatitis: results from a phase IIa open-label trial and subsequent phase III open-label extension. Br J Dermatol 2020, 182, 85-96.

40. de Bruin-Weller M., Thaçi D., Smith C., Reich K., Cork M.J., Radin A.: Dupilumab with concomitant topical corticosteroid treatment in adults with atopic dermatitis with an inadequate response or intolerance to ciclosporin $\mathrm{A}$ or when this treatment is medically inadvisable: a placebo-controlled, randomized phase III clinical trial (LIBERTY AD CAFÉ). Br J Dermatol 2018, 178, 1083-1101.

41. Simpson E.L., Flohr C., Eichenfield L.F., Bieber T., Sofen H., Taïeb A., et al.: Efficacy and safety of lebrikizumab (an anti-IL-13 monoclonal antibody) in adults with moderate-to-severe atopic dermatitis inadequately controlled by topical corticosteroids: a randomized, placebo-controlled phase II trial (TREBLE). J Am Acad Dermatol 2018, 78, 863-71e811.

42. Wollenberg A., Howell M.D., Guttman-Yassky E., Silverberg J.I., Kell C., Ranade K., et al.: Treatment of atopic dermatitis with tralokinumab, an anti-IL-13 mAb. J Allergy Clin Immunol 2019, 143, 135-141.

43. Ruzicka T., Hanifin J.M., Furue M., Pulka G., Mlynarczyk I., Wollenberg A., et al.: Anti-interleukin-31 receptor A antibody for atopic dermatitis. N Engl J Med 2017, 376, 826-835.

44. Silverberg J.I., Pinter A., Pulka G., Poulin Y., Bouaziz J.D., Wollenberg A., et al.: Phase 2B randomized study of nemolizu$\mathrm{mab}$ in adults with moderate-to-severe atopic dermatitis and severe pruritus. J Allergy Clin Immunol 2020, 145, 173-182.

45. Kabashima K., Furue M., Hanifin J.M., Pulka G., Wollenberg A., Galus R., et al.: Nemolizumab in patients with moderate-to-severe atopic dermatitis: randomized, phase II, long-term extension study. J Allergy Clin Immunol 2018, 142, 1121-1130e7.

46. Guttman-Yassky E., Brunner P.M., Neumann A.U., Khattri S., Pavel A.B., Malik K., et al.: Efficacy and safety of fezakinumab (an IL-22 monoclonal antibody) in adults with moderate-to-severe atopic dermatitis inadequately controlled by conventional treatments: a randomized, double-blind, phase 2a trial. J Am Acad Dermatol 2018, 78, 872-881.

47. Chen Y.L., Gutowska-Owsiak D., Hardman C.S., Westmoreland M., MacKenzie T., Cifuentes L., et al.: Proof-of-concept clinical trial of etokimab shows a key role for IL-33 in atopic dermatitis pathogenesis. Sci Transl Med 2019, 11, eaax2945.

48. Simpson E.L., Parnes J.R., She D., Crouch S., Rees W., Mo M., et al.: Tezepelumab, an anti-thymic stromal lymphopoietin monoclonal antibody, in the treatment of moderate to severe atopic dermatitis: a randomized phase 2a clinical trial. J Am Acad Dermatol 2019, 80, 1013-1021.

49. Nakagawa H., Iizuka H., Nemoto O., Shimabe M., Furukawa Y., Kikuta N., et al.: Safety, tolerability and efficacy of repeated intravenous infusions of KHK4083, a fully human anti-OX40 monoclonal antibody, in Japanese patients with moderate to severe atopic dermatitis. J Dermatol Sci 2020, 99, 82-89.

50. Guttman-Yassky E., Pavel A.B., Zhou L., Estrada Y.D., Zhang N., Xu H., et al.: GBR 830, an anti-OX40, improves skin gene signatures and clinical scores in patients with atopic dermatitis. J Allergy Clin Immunol 2019, 144, $482-493$.

51. Gooderham M.J., Forman S.B., Bissonnette R., Beebe J.S., Zhang W., Banfield C., et al.: Efficacy and safety of oral janus kinase 1 inhibitor abrocitinib for patients with atopic dermatitis: a phase 2 randomized clinical trial. JAMA Dermatol 2019, 155, 1371-1379.

52. Simpson E.L., Sinclair R., Forman S., Wollenberg A., Aschoff R., Cork M., et al.: Efficacy and safety of abrocitinib in adults and adolescents with moderate-to-severe atopic dermatitis (JADE MONO-1): a multicentre, double-blind, randomised, placebo-controlled, phase 3 trial. Lancet 2020, 396, 255-266.

53. Guttman-Yassky E., Silverberg J.I., Nemoto O., Forman S.B., Wilke A., Prescilla R., et al.: Baricitinib in adult patients with moderate-to-severe atopic dermatitis: a phase 2 parallel, double-blinded, randomized placebo-controlled multiple-dose study. J Am Acad Dermatol 2019, 80, 913-921.e9.

54. Simpson E.L., Lacour J.P., Spelman L., Galimberti R., Eichenfield L.F., Bissonnette R., et al.: Baricitinib in patients with moderate-to-severe atopic dermatitis and inadequate response to topical corticosteroids: results from two randomized monotherapy phase III trials. Br J Dermatol 2020, 183, 242-255.

55. Beck L., Hong C., Hu X., Chen S., Calimlim B., Teixeira H., et al.: Upadacitinib effect on pruritus in moderate-to-severe atopic dermatitis: from a phase 2b randomized, placebo-controlled trial. Ann Allergy Asth Immunol 2018, 121, S21.

56. Guttman-Yassky E., Thaçi D., Pangan A.L., Hong H.C.H., Papp K.A., Reich K., et al.: Upadacitinib in adults with moderate to severe atopic dermatitis: 16-week results from a randomized, placebo-controlled trial. J Allergy Clin Immunol 2020, 145, 877-884.

57. Levy L.L., Urban J., King B.A.: Treatment of recalcitrant atopic dermatitis with the oral Janus kinase inhibitor tofacitinib citrate. J Am Acad Dermatol 2015, 73, 395-399.

58. Bissonnette R., Papp K.A., Poulin Y., Gooderham M., Raman M., Mallbris L., et al.: Topical tofacitinib for atopic dermatitis: a phase IIa randomized trial. Br J Dermatol 2016, 175, 902-911.

59. Kim B.S., Sun K., Papp K., Venturanza M., Nasir A., Kuligowski M.E.: Effects of ruxolitinib cream on pruritus and quality of life in atopic dermatitis: results from a phase 2, randomized, dose-ranging, vehicle- and active-controlled study. J Am Acad Dermatol 2020, 82, 1305-1313.

60. Nakagawa H., Nemoto O., Igarashi A., Saeki H., Kaino H., Nagata T., et al.: Delgocitinib ointment, a topical Janus kinase inhibitor, in adult patients with moderate to severe atopic dermatitis: a phase 3, randomized, double-blind, vehicle-controlled study and an open-label, long-term extension study. J Am Acad Dermatol 2020, 82, 823-831. 
61. Nakagawa H., Nemoto O., Igarashi A., Nagata T.: Efficacy and safety of topical JTE-052, a Janus kinase inhibitor, in Japanese adult patients with moderate-to-severe atopic dermatitis: a phase II, multicentre, randomized, vehicle-controlled clinical study. Br J Dermatol 2018, 178, 424-432.

62. Nakagawa H., Nemoto O., Igarashi A., Saeki H., Oda M., Kabashima K., et al.: Phase 2 clinical study of delgocitinib ointment in pediatric patients with atopic dermatitis. J Allergy Clin Immunol 2019, 144, 1575-1583.

63. Piscitelli S., Lee J., McHale K., Collins J., Gillmor D., Tabolt G., et al.: Cerdulatinib (DMVT-502), a novel, topical dual Janus kinase/spleen tyrosine kinase inhibitor, improves the cellular and molecular cutaneous signature in patients with atopic dermatitis. Exp Dermatol 2018, 27, S2.

64. Bissonnette R., Maari C., Forman S., Bhatia N., Lee M., Fowler J., et al.: The oral Janus kinase/spleen tyrosine kinase inhibitor ASN 002 demonstrates efficacy and improves associated systemic inflammation in patients with moderate-to-severe atopic dermatitis: results from a randomized double-blind placebo-controlled study. Br J Dermatol 2019, 181, 733-742.

Received: 23.09 .2020

Accepted: 1.11 .2020

Otrzymano: 23.09.2020 r.

Zaakceptowano: $1.11 .2020 \mathrm{r}$.

\section{How to cite this article}

Nowicki R.J., Trzeciak M., Rudnicka L., Szepietowski J., Kulus M., Kupczyk M., Mastalerz-Migas A., Peregud-Pogorzelski J., JahnzRóżyk K., Narbutt J., Czarnecka-Operacz M., Czajkowski R., Grubska-Suchanek E., Krasowska D., Kręcisz B., Kowalewski C., Lesiak A., Olszewska M., Samochocki Z., Śpiewak R., Wilkowska A.: Biological drugs in the treatment of atopic dermatitis - recommendations of the Polish Dermatological Society, the Polish Society of Allergology, the Polish Pediatric Society and the Polish Society of Family Medicine. Dermatol Rev/Przegl Dermatol 2020, 107, 409-423. DOI: https://doi.org/10.5114/dr.2020.10166. 